\title{
Implementation of Islamic Management based on Maqasid Sharia in Information Services Company (Case Study: Islamic Analytix Singapore)
}

\author{
Wily Mohammad, Dian Tiara Nurhasanah \\ Padjadjaran University, Bandung, West Java 40132, Indonesia \\ Padjadjaran University, Bandung, West Java 40132, Indonesia \\ Email: wily17001@mail.unpad.ac.id, and dian17001@mail.unpad.ac.id
}

\section{ARTICLE INFO}

Date received : 10 January 2021

Revision date : 14 February 2021

Date received : 20 March 2021

\section{Keywords:}

Islamic

Management

Maqasid Sharia

\section{ABSTRACT}

Management is the art of regulating the process of utilizing human resources and other sources effectively and efficiently to achieve certain goals. Management has been used by many companies in this world, also has been influenced by social values including religion. Muslims who always adhere to Islamic law as a way of life properly will receive benefits in the form of Maqasid Sharia based on the level of Maslahah given by Allah. Humans, as the manager for themselves, for their family, or for their organization also really need to protect things in the concept of Maqasid Sharia and determine the level of protection using the concept of Maslahah. This can also be applied to companies, especially if its people are muslim, to make the company, management, and the people therein happy, live long, and blessed by Allah. Islamic Analytix is an Information Services company based in Singapore. This company provides Market Research, Market Analytics, and Market Intelligence through the platform. The staff, managers, and directors are mostly Muslim. The result of this research shows that Islamic Analytix Singapore is implementing Islamic management based on Maqasid Sharia. It can be seen from the good religious attainment (ad-Din), good quality of the life (an-Nafs), good quality of science or intellect (al-Aql), good quality of offspring (an-Nasl), and good quantity of wealth (al-Maal). These results also according to the maslahah concept such as primary needs (dharuriyyat), secondary needs (hajjiyyah), and tertiary needs (tahsiniyyah). 


\section{INTRODUCTION}

Management is the art of regulating the process of utilizing human resources and other sources effectively and efficiently to achieve certain goals. According to G.R. Terry, management is a typical process, which consists of planning, organizing, mobilizing and controlling actions carried out to achieve predetermined goals through the use of human resources and other resources (Hasibuan M. S., 2017). According to Stoner, management is the process of planning, organizing, directing, and supervising the efforts of members and the use of other organizational resources in order to achieve predetermined organizational goals (Choliq, 2014). From some of the definitions above, it can be concluded that management is a series of activities to plan, organize, mobilize, control and develop all efforts to regulate and utilize human resources, facilities and infrastructure to achieve organizational goals that have been set effectively and efficiently.

Management, both as a science and practice, is one of the main factors driving the development of large industries since the 17th century industrial revolution. Thanks to the development of management science, so resource management in industries and companies can be done better. In addition, cooperation between large industries and large universities has prompted the rapid advancement of management science. Therefore, the importance of management for the progress of small and large organizations makes more people learn, develop, and implement management (Mas'Ud, 2004).

Management that is developed in various places can be influenced by the social values believed in the place where it develops. Management developed by experts from the West such as the United States, is of course based on the Western worldview, and contains values that are believed and embraced by the experts who develop it. For example, in Western, European, and American civilizations, science is separated from religion. This is a legacy of the conflict between institutionalized Christianity and science based on rationality that developed from the time of the Age of Enlightenment (Mas'Ud, 2004).

The social values can influence the areas where the manager demonstrates the tasks and the implementation of the strategies. There are several factors that contribute to the formation and perpetuation of culture or social values, where religion is one but not the only one. Religion is one of the things that has a big influence on the development of society, especially in terms of culture and social values therein (Tayeb, 1997).

Islam is one of the largest religions practiced by Muslims in the world. One of its teachings is to ensure the happiness of the life of its adherents in the world and in the hereafter as stated in the Al-Qur'an and Hadith (Shihab, 2007). There are approximately 1.9 billion Muslims globally, making Islam the second-largest religion in the world behind Christianity. Islam is the dominant religion in several countries, including Afghanistan, Pakistan, Western Sahara, Iran, and more. Countries with high numbers of Muslims tend to be in Africa, the Middle East, and Asia (Review, 2021).

Islam as the way of life regulates the muāmalah aspect. Muāmalah means activities related to human relations. The study of Islamic law about muāmalah is broadly related to two things. First, muāmalah which relates to the necessities of life related to matter and this is what is called economy. Second, muāmalah which is related to social life which is linked by the moral interests of humanity (Zakki, 2002). Based on these definitions, management is included in muāmalah, because management includes the activities related to human relations and social life.

In the Islamic point of view, management is termed by using the word attadbir that means regulation (Ramayulis, 2008). This word is a derivation from the word dabbara that means manage / regulate, which is widely found in the Al-Qur'an as said by Allah:

"He regulates every affair from the heavens to the earth, then it all ascends to Him on a Day whose length is a thousand years by your counting" (Al-Qur'an Surah AsSajdah verse 5).

From the contents of the above verse, it can be seen that Allah is the manager of universe (Al Mudabbir / manager). The order of the universe is proof of the greatness of Allah in managing this universe. However, because Allah created humans as the caliph / leader on earth, then humans must manage 
the earth as best as possible as Allah manages this universe (Goffar, 2016).

One of the important and fundamental concepts in Islam is Maqasid Sharia. This is the goal of being religious in Islam. The concept of Maqasid Sharia is the initial gateway that must be passed, so that Islam as a religion is able to implement its expectations (Goffar, 2016). Maqasid Sharia is the goal of the presence of Islamic law from Allah to humans. Humans can be noble and alive, if they protect their religion, body and soul, mind, offspring, and wealth (Hadi, 2013).

The Islamic scholars provide an overview of Maqasid Sharia, that must be centered and resting on five main points of benefit (because these are protected), those are: the protection of religion (hifz al-din), the protection of the life (hifz al-nafs), the protection of mind (hifz al-aql), the protection of the offspring (hifz al-nasl), and the protection of wealth (hifz al-maal).

Then, each of the protection has its level of protection that called Maslahah concept, those are: primary needs (dharuriyyat), secondary needs (hajjiyyat) and complementary / tertiary needs (tahsiniyyat). In the determination of the law, this ranking order will show its importance when it conflicts with its benefit. The dharuriyyat rank took the first rank, then the hajjiyyat preceded the tahsiniyyat rank. It could be interpreted that the third rank complements the second rank, and the first rank is complemented by the second rank (Goffar, 2016). The ranking of Maslahah concept and the relationship with Maqasid Sharia can be seen in this Figure 1:

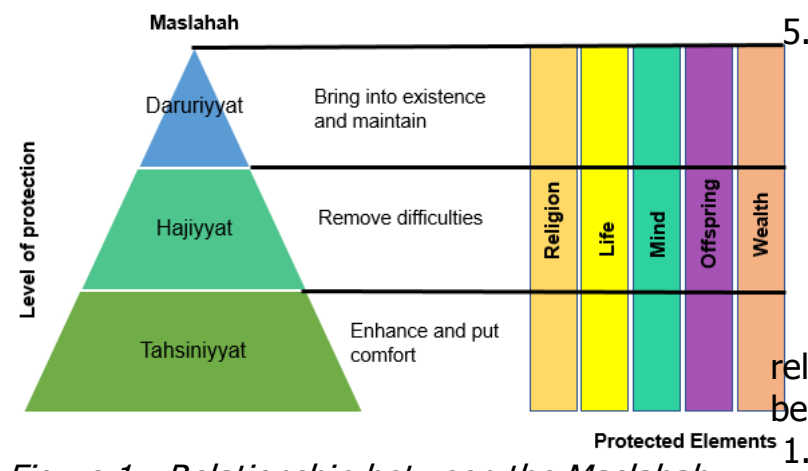

Figure 1 : Relationship between the Maslahah Concept and Doctrine of Shari'ah Objectives (Jalil, 2006).
The Maqasid Sharia concept and its relationship in management and company can be explained as follows (Hadi, 2013):

1. Protection of religion (hifz al-din)

Sharia compliance must be run in Islamic company for their management and business activity. If a company does not state as an Islamic company, but in running its business it is not against the sharia rules, then this company can also be considered as an Islamic company. Because based on the law of origin of muamalah, only companies that violate Islamic law are categorized as nonIslamic companies.

2. Protection of the life (hifz al-nafs)

Life factor in the Maqasid Sharia is analogous to the activities, sales, or income factor in the company. If the company can't get any activities and income, the company can be "sick" and threatened with bankruptcy.

3. Protection of mind (hifz al-aql)

Mind factor in the Maqasid Sharia is an analogous to the organizational system factor on company and there must be a leader of the team. Synergy between the leader and the organization that has different skills (mind and intellectual) can make their business development better.

4. Protection of the offspring (hifz al-nasl)

Offspring factor in the Maqasid Sharia is analogous to the profit and blessing factors of the company. Profits are related to quantitative, while blessings are related to qualitative. Good activity, sale of products or services contains a lot of profit and a lot of blessings from Allah.

5. Protection of wealth (hifz al-mal)

Wealth factor in the Maqasid Sharia is analogous to the capital factor and financial management in a company. If a complete company system is in place, but if there are no funds, then the system is difficult to run properly.

The Maslahah concept and its relationship in management and company can explained as follows (Hadi, 2013):

Dharuriyyat (primary needs) refers to maintaining essential needs for human life in relation to the Maqasid sharia within the limit that their existence is not threatened. This means that not fulfilling 
the needs of this level of dharuriyyat will threaten the existence of human life. In this article, we'll see the nature and point of view of dharuriyyat from the company's perspective. It means anything if these factors do not exist, there will be destruction or bankruptcy.

2. Hajjiyyat (secondary needs) refers to something that should exist so that it is carried out freely and avoid difficulties. If this thing does not exist, then it will not cause damage or death, it will just result in narrowness. Hajjiyyat factors should be present in the company, so that the company is free to move and does not experience difficulties in building muamalah relationships with its customers.

3. Tahsiniyyat (tertiary needs) is something that should exist for the sake of harmony with good moral imperatives with customer. If this something does not exist, then it will not cause damage or loss of something nor will it cause badness in doing it, it's just that it is considered inappropriate and unworthy according to the standards of courtesy and decency.

In a short explanation, Muslims who always adhere to Islamic law as a way of life properly will receive benefits in the form of Maqasid Sharia based on the level of Maslahah given by Allah. Humans, as the manager for themselves, for their family, or for their organization also really need to protect things in the concept of Maqasid Sharia and determine the level of protection using the concept of Maslahah. This can also be applied to companies, especially if its people are muslim, to make the company, management, and the people therein happy, live long, and blessed by Allah.

Islamic Analytix is an Information Services company based in Singapore that was built on September 2020. This company provides informations Market Research, Market Analytics, and Market Intelligence through the platform. Driven by the principles of Islamic Finance and economics and leveraging today's hottest technologies, the Islamic Analytix team is unleashing up to the minute market research, transparency and intelligence to Islamic Finance practitioners. This company also been producing Islamic educational content and some discussions about Islamic financial technology and Islamic updates on an online group discussion that includes more than 300 people. This company also have more than 1900 people following on their page. The people in this company come from several regions of the world. For example, the managers and directors are from Canada and Singapore, the staff are from Indonesia, Nigeria, and Kazakhstan. Most of the team (87\%) are muslims (Sabir, Interview: Islamic Analytix Company, 2021).

Knowing that this company is engaged in Islamic economic and finance informations and contains majority of Muslims as their staff and directors, of course this company should implement the management in accordance with sharia principles, so that there will be good and smooth in their activities, also may get blessings from Allah.

In this research, to determine the implementation of Islamic management, we use the concept of Maqasid Sharia and its relationship with the concept of maslahah. In this way, it can be seen whether this company has implemented Islamic management based on Maqasid Sharia or not.

The purpose of this research is to know the implementation of Islamic management based on Maqasid Sharia (such as religious attainment, quality of the life, quality of science or intellect, quality of offspring, and quantity of assets or wealth) in Islamic Analytix Singapore. The benefit of this research is as an additional literature study for those who will conduct similar research in the future, and to improve the understanding and implementation of Islamic management in this world.

\section{METHOD}

This type of research is qualitative. Qualitative research is a process of understanding that is carried out continuously by observing certain situations or social phenomena and human problems that occur in everyday life. In other words, qualitative research tries to understand what phenomena occur in research subjects, both attitudes, behavior and views of a person, and is reported by means of descriptions in the form of words (Sugiyono, 2019).

Data obtained from respondents using interview methods and in-depth observation to find out about the practice of implementing Islamic management based on Maqasid 
Sharia at the Islamic Analytix Singapore company. The data collection was carried out by taking samples in the form of Directors, Managers, and staff at Islamic Analytix Singapore. Data analysis in this research using methods:

1. Data Reduction.

Data reduction is a sharp analysis to organize data, so that the conclusion can be diversified to be used as research findings on the problem under study (Iskandar \& Pd, 2009). Because the main purpose of qualitative research itself is findings. Data reduction activities will be guided by the research objectives to be achieved. It is hoped that the data that has been reduced by the researcher can provide a clearer picture. This process will take place continuously as long as the research is carried out. The method to determine the implementation of Islamic management, we use the concept of Maqasid Sharia and its relationship with the concept of maslahah. In this way, it can be seen whether this company has implemented Islamic management based on Maqasid Sharia or not. This Islamic management method is adapted from a research from Hadi Kuncoro under the title "Manajemen Perusahaan Berbasis Maqashid Syariah" (Hadi, 2013).

2. Presentation of Data.

Presentation of research data will make data structured systematically. The data obtained with a lot of research will not be able to be described as a whole. By presenting the data, the researcher will analyze which data can explain or answer the problem in the research. Presentation of data can be in the form of text, charts, networks, graphs or matrices by combining the information obtained in a compact manner in order to see what really happened and make it easier to draw conclusions in accordance with the actual situation. What is often used in qualitative research to present research data is in the form of narrative text (Iskandar \& Pd, 2009).

3. Taking conclusions.

Taking conclusions can be descriptive as a report in the study. In qualitative research, drawing conclusions is expected to answer the formulation of problems that have been determined from the start and support the findings in the study. The conclusions in qualitative research are new findings that have never existed before. The findings themselves can be in the form of descriptions or descriptions of an object (Iskandar \& Pd, 2009).

4. Data Validation.

Validity is the degree of accuracy between the data that occurs on the object of research and the power that can be reported by the researcher (Sugiyono, 2019) In other words, the data will be called valid if the data reported by the researcher matches the data that occurs on the research object. Researchers confidently report interpretations based on data actually obtained from the field. To obtain valid and reliable data in qualitative research, testing is more focused on the data. Stainback quoted by (Sugiyono, 2019) states that qualitative research emphasizes the validity aspect. There are two validities of research, namely internal validity and external validity.

5. Internal Validation.

In this research, the internal validity test or the confidence test of the research data was carried out using the member check technique. Member check is a check conducted by researchers to participants on findings reported by researchers, whether these findings are accurate according to participants. Checking is carried out by the researcher by asking the participants whether the data that has been interpreted by the researcher are appropriate from the point of view of the data provider. Participants can give member checks to the checklist column if the participants agree with the results of the researcher's interpretation. However, if the participant does not agree with the results of this interpretation, the participant has the right not to give a member check and ask the researcher to correct it (Iskandar \& Pd, 2009).

6. External Validation.

In this research, the external validity or credibility test concerns the application of the research results, that is, the degree of accuracy in the application of the research results to the study population. The credibility test depends on the extent to which the results of the 
study can be applied to the population from which the sample was taken or other similar social situations. In making a qualitative research report, the researcher must provide a detailed, systematic, clear and reliable description so that other people can understand the results of the research so that it can be applied to actual social situations (Iskandar \& Pd, 2009).

\section{RESULTS AND DISCUSSION}

Based on the data obtained from some sources and referring to the method to determine the implementation of Islamic management based on Maqasid Sharia in Islamic Analytix Singapore, the results are:

1. Religion (ad-Din) from the company perspective:

a. Dharuriyyah: [1] This company maintain and carry out religious obligations before meeting with their staff. [2] Manager reminds their staff to do sholat and pray first before work. [3] This company spread Islamic knowledge (as a da'wah value) to the community group, islamic finance practicioner, and many muslim people.

b. Hajjiyyah: [1] This company carry out religious provisions with the aim of avoiding difficulties. [2] Manager and Admin give "salaam" greeting to others when opening the discussion or chats. [3] Employee in this company work together with discussions and helping each other by asking for no return but from Allah, and they acknowledge that Allah has control over everything. [4] Manager and Admin regularly say: "alhamdulillah", "mashaAllah", and "jazakallah khairan" to make their staff always remember to Allah, and they make it as a good habit in their daily basis. [5] Manager and Admin give turn to the staff and community to give their opinion about anything related to Islam and technology.

c. Tahsiniyyah: [1] The company's name and their community's group name contains "Islamic" word on it. This shows that they are obliged to apply "Islamic" principles to their management and activities, as indicated in their name.

2. Life (an-Nafs) from the company perspective: a. Dharuriyyah: [1] This company meets the core of their needs such as services in the area of informations to Islamic finance practicioner to sustain the company. [2] They also have a meeting with investor to get investment from them. [3] They have been producing contents to make this company alive and gives value to others.

b. Hajjiyyah: [1] This company services are halal (permissible in Islam) and thoyyib (good) guaranteed for consumers, because they does not violate sharia principles on their business. [2] The informations offered by this company are transparent and clear with the written sources of the data.

c. Tahsiniyyah: [1] This company beautify their platform and contents with animation, unique quadrant, mapper, clicker, and color, so that it is attractive to be clicked and read. [2] This company gives a lock and code to open the webpage, so that this webpage can be exclusive to the reader because they provide some valueable contents.

3. Mind (al-Aql) from the company perspective:

a. Dharuriyyah: [1] This company has a leader such as Directors and Managers. [2] They also have organizational structure. [3] They also giving task to the staff according to their abilities and specializations.

b. Hajjiyyah: [1] This company provides training to their staff to increase the abilities and knowledges through the online courses provided. [2] Manager gives tutorial or some examples to the staff on how to do their task smoothly. [3] Manager always appreciate the progress of the staff's work.

c. Tahsiniyyah: [1] This company has a discussion community from some Islamic organizations such as INCEIF, CFA Institute, CIBE-UAE, Doha Islamic Finance, IBE, etc.

4. Offspring (al-Nasl) from the company perspective:

a. Dharuriyyah: [1] This company providing value and gets some benefits from their information services and also expecting blessings from Allah. [2] 
They generate their services for muslim to be blessed by Allah.

b. Hajjiyyah: [1] This company have been producing Islamic contents so that Allah may give mercy to this company. [2] Manager and staff have some plans on producing useful content for the future, such as Islamic banks report, Islamic webinar, etc. to give benefits to others so that Allah may give sustenances and good fortune.

c. Tahsiniyyah: [1] This company promotes their services clearly and well described using some social media. [2] This company also promotes their services with short message including "salaam"on it.

5. Wealth (al-Mal) from the company perspective:

a. Dharuriyyah: [1] According to the Director, this company knows about the procedures for capital and the use of property according to the Sharia principles. [2] They understand the obligation to pay zakat for individuals and company, and they pay zakat and shadaqah regularly. [3] This company provides a clear contract to their staff that contains: start date, finish date, job descriptions, and salary per month. They also pay their employee on time in accordance with the written contract. [4] This company uses their funds wisely, responsible for its use, and believe in accountability to Allah.

b. Hajjiyyah: [1] This company has provisions for the fees to the staff in accordance with the Sharia, that sufficient for necessity. They also open for any calculation of fees adjustment. [2] Manager often asks to the staff about the difficulties in the process of sending salaries and gives the alternative methods to do it easily.

c. Tahsiniyyah: [1] This company has provisions on avoiding fraud, bribery, and haram things. [2] This company has provisions on avoiding sin and enmity.

\section{CONCLUSIONS}

These conclusions in this research aims to be able to answer the following problem questions:
1. The result shows that Islamic Analytix Singapore is implementing Islamic management based on Maqasid Sharia.

2. It can be seen from the good religious attainment (ad-Din), good quality of the life (an-Nafs), good quality of science or intellect $(a l-A q I)$, good quality of offspring (an-Nasl), and good quantity of wealth (alMaal). These results also according to the maslahah concept such as primary needs (dharuriyyat), secondary needs (hajjiyyah), and tertiary needs (tahsiniyyah).

\section{REFERENCES}

Choliq, A. (2014). Introduction of Management. Yogyakarta: Penerbit Ombak.

Goffar, A. (2016). Manajemen dalam Islam (perspektif al-Qur'an dan hadits). Islamic Akademika: Jurnal Pendidikan Dan Keislaman, 8(1), 35-58. Google Scholar

Hadi, K. (2013). Manajemen perusahaan berbasis maqoshid syariah. Jurnal AlAzhar Indonesia Seri Pranata Sosial, 2(1), 39-46. Google Scholar

Hasibuan, M. S. (2017). Manajemen Sumber Daya Manusia. Jakarta: Bumi Aksara. Google Scholar

Iskandar, D., \& Pd, M. (2009). Metodologi penelitian pendidikan dan sosial (kuantitatif dan kualitatif). Jakarta: Gaung Persada Press. Google Scholar

Jalil, A. (2006). The significances of Maslahah concept and doctrine of Maqasid (Objectives) Al-Shari'ah in project evaluation. The Journal of Muamalat and Islamic Finance Research (JMIFR), 3(1), 171-202.

Mas'Ud, F. (2004). Survai diagnosis organisasional konsep dan aplikasi. Badan Penerbit Universitas Diponegoro. Google Scholar

Ramayulis, I. P. I. (2008). Kalam Mulia. Jakarta. 
Review, W. P. (2021). World Population Review. Muslim Population by Country 2021.

Sabir, A. (2021). Interview: Islamic Analytix Company. (D. T. Nurhasanah, \& W. Mohammad, Interviewers)

Shihab, M. Q. (2007). " Membumikan" A/Quran: fungsi dan peran wahyu dalam kehidupan masyarakat. Mizan Pustaka. Google Scholar

Sugiyono. (2019). Metode Penelitian
Kuantitatif, Kualitatif, Dan R\&D. Bandung: Alfabeta.

Tayeb, M. (1997). Islamic revival in Asia and human resource management. Employee Relations. Google Scholar

Zakki, A. (2002). Economics in an Islamic Perspective. Bandung: Pustaka Setia.

\section{Copyright holder:}

Wily Mohammad, and Dian Tiara Nurhasanah (2021)

First publication right:

Journal of Social Science (JSS)

This article is licensed under:

(c) (7) (? 